10.2478/genst-2018-0004

THE OTHER HALF OF THE TRUTH:

\title{
INCIDENTS IN THE LIFE OF A SLAVE GIRL, A FIRST-HAND ACCOUNT OF SLAVERY FROM A WOMAN'S PERSPECTIVE
}

\author{
ŞERBAN DAN BLIDARIU \\ West University, Timişoara \\ 4, V. Pârvan Blvd, 300223 Timișoara, Romania \\ blidariu.serban@gmail.com
}

\begin{abstract}
While Frederick Douglass' autobiography is a classic and offers an image of slavery based on the memories of a former slave, that image remains incomplete because it is centered on attributes and events seen as predominantly masculine. For a more thorough understanding of what slavery was for all, another perspective must be put forth: that of a woman and a mother. In order to achieve this, the paper will focus on Incidents in the Life of a Slave Girl by Harriet Jacobs.
\end{abstract}

Keywords: abuse, autobiography, freedom, racism, slavery.

\section{Introduction}

The issue of transmission of reality is a valid concern for any text in which the author makes the claim of truthfulness. It is no surprise, then, that slave autobiographies were often dismissed as falsehoods or as exaggerations. Nonetheless, many texts authored by fugitive or former slaves continued to be printed in the United States around the mid-nineteenth century because they persisted in giving voice to experiences that could no longer be silenced. While slave autobiographies served the aims of white abolitionists, a number of whom were racist, the texts were also in the service of a higher purpose: raising public awareness regarding horrors that rarely caught the public's attention. However, back then as well as in literary studies of slavery today, there is a demand for authenticity that can only be described as being "paradoxically urgent", even though most readers are aware that it can never be fully achieved: "I say paradoxically because the 
demand that a text, any text, be entirely true to experience is an illogical demand. Representation is mediation. No representation can ever completely capture experience.” (Smith 2007:194-195)

Yet the demand persisted in the pre-Civil War period, with the obvious intervention of those who wanted slavery to disappear from the United States. It must not be believed, however, that abolitionist efforts were the main cause that led to the existence of slave autobiographies. Ironically as it might seem when analyzed in hindsight, I agree with Cindy Weinstein and believe that the root cause was the institution of slavery itself. The actual experience of bondage

which ought to preclude the production of narrative, instead becomes the logical consequence, if not necessity, of those who escape the grasp of the peculiar institution. Slavery paradoxically becomes the foundation of literary production. (Weinstein 2007:119)

Among the many narratives authored by slaves and published around that period, at least two almost always stand out: Incidents in the Life of a Slave Girl, Written by Herself, by Harriet Jacobs and Narrative of the Life of Frederick Douglass, an American Slave, by Frederick Douglass. Beyond issues such as pure authenticity and truthfulness, though, something else characterized texts of this kind: they had one common goal. They were "a text with a purpose: the abolition of slavery" (Fisch 2007:2). That made them "intensely political documents" (Bruce 2007:28). It may have been the only general solution.

\section{A Short Account of the 'Masculine' Perspective on Slavery and Freedom}

In his first autobiography, Frederick Douglass presents himself as a character destined to be free since birth. For him slavery was "tantamount to apostasy: a spiritual death with no possibility of an afterlife" (Stauffer 2007:156). The story is constructed in such a way as to present how he moved ever closer to freedom and how his personal determination was a big factor. Two crucial moments stand out.

The first event was preceded by the fact that Mrs. Auld, the wife of his owner, decided to teach him the letters. However, the husband found out and told her that learning can spoil the best slave. Overhearing the conversation, Douglass realized the surety behind his master's words and thus became determined to continue this path on his own but with the help of poor white children, without the knowledge of his owner (Douglass 2009:38-43). The more he learned, the more Douglass understood the situation he was in. 
The second moment was caused by the fact that he was lent for a year to Covey, an overseer known for being a slave breaker. This meant that Covey was one of the people who were sometimes asked to break a slave's willpower and cow them into submission. One day Covey decided to whip him but Douglass chose to fight back. Covey promised he would do terrible things but was unable to overpower him. He did not go through with his threats because calling for outside help would have ruined his reputation. Douglass describes this turning point in his life as follows: "You have seen how a man was made a slave; you shall see how a slave was made a man." (Douglass 2009:6368) A new contradiction is brought forth: the opposition between 'man' and 'slave'. The two terms are constructed on different sides of the idea of independence from another's will: a slave does not have it and the feeling is almost extinguished, while a man either has liberty or is willing to fight for it.

\section{Admitting the Effects of Slavery Both on the Enslaved and as One's Weaknesses}

Unlike Frederick Douglass, who constructed his autobiography in such a way as to appear that his freedom was a goal set by fate and that he was an exceptional character, Harriet Jacobs presents her story in a more down-to-earth way. Given this approach, there was an even higher level of skepticism directed toward Incidents in the Life of a Slave Girl. It was considered less authentic because the author chose to focus on the domestic instead of centering on self-reliance (Smith 2007:191). Just like the author, but in a different manner, the text "was long ignored or devalued because it was an exception" and this happened for the longest part of its existence (Ernest 2007:219). From the first words of the Preface, Jacobs affirms that she had no formal education. While she did go to great lengths to improve her reading and writing skills after she had run away, she is open about the fact that her abilities may not be as strong as she wanted them: "I wish I were more competent to the task I have undertaken. But I trust my readers will excuse deficiencies in consideration of circumstances. I was born and reared in slavery.” (Jacobs 2000:3)

To some extent, Douglass actually wrote his first autobiography in order to communicate, among other things, how he became so eloquent that many people asked themselves if he could ever have been a slave. Harriet Jacobs, even though she did not have such a spectacular rise in the anti-slavery circles as Douglass, was in her own way remarkable for she wrote her autobiography herself and claimed this achievement in the title of her text. What she did not do from the beginning, though, was to divulge her identity. In the first edition all names were changed, including her own. 
The text was attributed to a Linda Brent. Her motivation may also have been her reflection on "the significant difference between the public perception of a man's degradation and a woman's" (Ernest 2007:220). Given the overall circumstances, her narrative was a great accomplishment in itself, her "marked contribution to American history and letters" (Painter 2000:IX). Also, if we are to pay attention to the details, we can see that Jacobs was instructed by her mistress in how to read, just like Douglass. The difference is that as long as that person was alive, the process was not hindered. The surprise came with the owner's death, for Jacobs believed she would be manumitted. Yet her hopes did not become fact.

As a child, I loved my mistress; and looking back at the happy days I spent with her, I try to think with less bitterness of this act of injustice. While I was with her, she taught me to read and spell and for this privilege, which so rarely befalls to the lot of a slave, I bless her memory. (Jacobs 2000:3)

As was often the case in slave narratives, in abolitionist fiction like Uncle Tom's Cabin or more recent novels like Toni Morrison's Beloved, the death of a humane master or the slave's removal from a benevolent owner can have drastic consequences. Slaves were usually directed towards the auction block, simply taken by a new owner according to the will of the former or following property legislation. While Jacobs remembered her first mistress in a very positive light, she did not hold the second one in the same high regard due to the way she and her husband ignored the feelings of enslaved persons. Not even when the passing of a loved one coincided with what they believed was her duty did her owners allow her time to mourn for a deceased family member.

I thought I should be allowed to go to my father's house the next morning; but I was ordered to go for flowers, that my mistress' house might be decorated for an evening party. I spent the day gathering flowers and weaving them into festoons, while the dead body of my father was lying within a mile of me. What cared my owners for that? I was merely a piece of property. (Jacobs 2000:12)

Painful as the separation may have been, there is no mention of her father's death as something caused by direct and violent abuse. It was the breaking up of families and keeping the living apart from each other that Jacobs really feared and criticized. The nightmarish thoughts of many enslaved mothers, the sale of their children, sometimes took form in real life. Moreover, the cause from time to time has its origin in another unchecked deployment of arbitrary power. More than just belonging to someone else and risking being overworked, a number of women in bondage 
were either sexually abused, deceived by their owners or even both. Harriet Jacobs describes a harsh case:

When the mother was delivered into the trader's hands, she said, 'You promised to treat me well' , to which he replied 'You have let your tongue run too far; damn you!' She had forgotten that it was a crime for a slave to tell who was the father of her child (Jacobs 2000:16).

This scene, with the slave's feelings being treated as if they just do not matter, is the consequence of considering slavery to be the equivalent of social death. Orlando Patterson claims that the powerlessness of the slave originated "as a substitute for violent death", a postponement even, where the "execution was suspended only as long as the slave acquiesced in his powerlessness" (Patterson 1982:5). The separation of families was not a subject the defenders of slavery could avoid or deny. However, they either claimed that it was a rare phenomenon or stated that familial ties and emotions were weaker in African descendants than in the case of European descendants. Arguments such as these were often countered in slave narratives (Bruce 2007:31).

Harriet Jacobs herself was almost a victim of sexual abuse from her master and she decided to refuse him directly. The fact that she lived in a small town where almost everybody knew everybody and rumors could spread quickly helped her for a while. However, she was aware that she would not be able to continue on this path for long and that her only way out, if any, was to enter into a sexual relationship with another white man. She was not proud of her decision and even felt shame because acting in this way was a direct betrayal of the principles taught by her rigidly moral grandmother. Nonetheless, the religious education Jacobs had received offered no protection from the possible abuser and her power of perception made her believe it was one way or the other: "I tried hard to preserve my self-respect, but I was struggling alone in the powerful grasp of the demon Slavery; and the monster proved too strong for me (...) I saw wither all this was tending." (Jacobs 2000:60) She was aware that speaking plainly about this would make other people judge and condemn what she had done. Harriet Jacobs accepted this possibility but also made clear to her readers, especially the female audience, that while she was a woman like all of them, many other facts of life were not the same: "You never knew what it is to be a slave; to be entirely unprotected by law or custom; to have the laws reduce you to the condition of a chattel, entirely subject to the will of another." (Jacobs 2000:62) She attempted to create a bond of womanhood across class and race. 


\section{Why Incidents in the Life of a Slave Girl Stands Out and How the Treatment of Women by Women is Not Neglected}

Incidents in the Life of s Slave Girl, Written by Herself stands out, first and foremost, because the autobiography was written by a woman who was formerly enslaved and who reminds the reader of this fact more than once. Thus, the text can be described as being the result of a "selfconsciously gendered" narrative. Many others, like the autobiography of Sojourner Truth for example, were only dictated by their authors to amanuenses and that fact alone may have "diluted the authenticity of the text" (Painter 2000:IX). The turmoil and suffering of enslaved women were not ignored in other slave narratives, but Harriet Jacobs did it more broadly, in book-length size. The uniqueness of her text, however, lies in the timing, for "Jacobs's is the only US book from this period that can represent the slave narrative genre from a woman's perspective, making the book representative, in effect, by default." (Ernest 2007:219) The text stands out not only because it was the only slave narrative written by a woman before the start of the Civil War but also because it paid more attention to the effects slavery had on women on both sides of the institution. But there is also another way to look at the issue of representativeness: viewing slave narratives as the success of a general struggle, for in their escape, runaway slaves were sometimes helped both by people they knew and by strangers. Thus, a description of one's struggle for freedom "may not be the fugitive's only story, but instead $a$ story that has come to stand for all others" (Rheid-Pharr 2007:146). Regardless of which interpretation is correct, it is still important to remember that one of Jacobs' achievements was how she presented the influence of slavery on human nature as a whole, not just the masculine side.

A positive case of female bonding led to the manumission of one of Jacobs' family members. After the death of her mistress, Harriet's grandmother ended up on the auction block, even though she should have been freed according to the will of her deceased owner. However, as this was not public knowledge, there was nothing she could do. Nonetheless, an old acquaintance decided to buy and free her soon after because she felt something must be done.

At last, a feeble voice said, 'fifty dollars'. It came from a maiden lady, seventy years old, the sister of my grandmother's deceased mistress. She had lived forty years under the same roof with my grandmother; she knew how faithfully she had served her owners, and how cruelly she had been defrauded of her rights; and she resolved to protect her. (Jacobs 2000:14) 
But Harriet Jacobs does not only describe the troubles of a woman enslaved. As a genderconscious text, the narrative also describes the effects of slavery on other women, turning them for the better or for the worst. Just like she was realistic with herself and did not embellish her education or literary qualities, she was realistic about the character flaws of other women, especially those wedded to slave owners. Thus, the negative traits of some do not escape either Harriet's observation or her pen. One of them was the wife of Dr. Flint, Jacobs' master and also the man who made advances towards her.

Mrs. Flint, like many southern women, was totally deficient in energy. She had not strength to superintend her household affairs; but her nerves were so strong that she could sit in her easy chair and see a woman whipped, till the blood trickled from every stroke of the lash. She was a member of the church; but partaking of the Lord's supper did not seem to put her in a Christian state of mind (Jacobs 2000:14).

Descriptions of masters who were more brutal than average and also held stronger religious convictions appeared in other abolitionist books as well, not only in slave autobiographies. One such text, The Testimonies of Angelina Grimke Weld describes, among other things, the behavior of a religious woman who abused her slaves both verbally and physically and even ordered family members to whip one another (Grimke Weld 2009:108-111).

Sometimes, a mistress' jealousy increased her hatred of certain slaves (mother and child) to overwhelming proportions. As Jacobs mentioned in a different paragraph, on some estates there was sexual intercourse between the owners and the enslaved women, young or mature. While what happened to some slave girls was taboo, it was not always a well-kept secret and assumptions always existed. The worst came when they were confirmed:

From others than the master, persecution also comes in such cases. I once saw a young slave girl dying soon after the birth of a child nearly white. In her agony she cried out 'O Lord, come and take me!' Her mistress stood by, and mocked at her like an incarnate fiend. 'You suffer, do you?' she exclaimed. 'I am glad of it. You deserve it all, and more too.' (Jacobs 2000:16)

This effect on the owner's family is barely mentioned so as to move away from its horrors. The issue is brought up again and again, each time showing the branching negative influence of slavery on all who come into contact with it, be they the owners or the legally but wrongfully 
owned. It is no surprise, then, that from the attitude of a mistress, from an early age some slave children could realize who may be the result of a master's abuse or his new favorite:

Everywhere the years bring to all enough of sin and sorrow; but in slavery the very dawn of life is darkened by these shadows. Even the little child, who is accustomed to wait on her mistress and her children, will learn before she is twelve years old, why it is that her mistress hates such a one among the slaves (Jacobs 2000:31).

Yet sometimes the deceit was successful and this was a skill that enslaved persons sometimes learned from their masters. While the narratives made claims of truthfulness, freedom was also achieved through dissimulation, for a fugitive slave often had to hide his or her identity, location or both. While many exposed themselves by writing their autobiographies, if they had done so earlier they may not have been able to write at all (Weinstein 2007:121). It may be worth to take into account, though, that some former slaves authored their narratives after someone purchased their freedom by paying their owners, like in the case of Jacobs. Whatever the reasons that led to Incidents being written, "multiple languages" were intersected: "sentimental, abolitionist, feminist and Christian ideologies". Another thing that Winter points out is the fact that by assigning the authorship of the text to a Linda Brent, Harriet Jacobs achieves two goals. The first and more obvious one was to hide her identity. The second, though, may have been her wish to create a certain gap between herself and the painful memories she relieves by putting them on paper (Winter 1992:42).

\section{Conclusion}

The classic autobiography written by an enslaved man focuses rather on the heroic attributes of the masculine slave, and others before and after followed the same logic when constructing the story. They did so "by representing themselves as isolated heroic subjects" that "defined their humanity in the terms of prevailing conceptions of American male identity" (Smith quoted in Ernest 2007:221). Today, Incidents in the Life of a Slave Girl is viewed as being "a corrective or counterbalance to the story of masculine struggle that Douglass presents in his Narrative". Thus, the classic slave narrative written by an enslaved woman centers mainly on the humanity of the women kept in bondage by "telling a different story, and also in telling similar stories differently" (Ernest 2007:221). Both their strengths and their flaws, from an early age to adulthood, are mentioned. By doing this and more, Jacobs claims that enslaved persons should not be judged by 
the same standards as the free if they stray from the moral path because they have been deprived of autonomy and influence. This does not mean that Douglass or any other formerly enslaved man had a different opinion but only that they decided not to focus on the issue in the same manner. Needless to say, given the moment when it was published and the interest of abolitionist circles, over time Frederick Douglass' first autobiography became a classic, while offering an image of bondage based on the memories of a former slave. However, that view remains incomplete because it is centered on attributes and events seen as predominantly masculine. For a more thorough understanding of what slavery was for all, another perspective must be brought forth: that of a woman and a mother.

While today we can read autobiographies written by formerly enslaved African-Americans for their historical and cultural importance, when they were published the situation was of a very different nature. What was written still held informative value but it also needed supporting proof that it was not false. It became common practice to have a white person write the preface and state that nothing was incorrect. Lydia Maria Child, the editor of Incidents, even added an additional letter from someone else: Amy Post (Gould 2007:25). In the preface to Douglass' Narrative, the abolitionist William Lloyd Garrison added that the story was completely real and unmodified by editorial interference and thus with no trace of fakeness (Sinanan 2007:79).

Women who owned or were the wives of slave owners take up a large part of the text. Without adding to the good or subtracting from the bad, Jacobs completes the image by not having only men as abusers or abused. While pro-slavery thoughts were prevalent in many Southern states and racist prejudices in many Northern areas, what a large majority of American citizens rejected was arbitrary power. For a country where the political system was based on the notion of 'checks and balances', if the anti-slavery campaign was to be successful it needed to focus on that. It did so by creating an image of "a slave regime that was the embodiment of arbitrariness" (Bruce 2007:40).

It took more than 100 years for the text to reach a large readership. However, Jacobs' autobiography never had an initial audience at the time it was published as wide as that of Douglass mainly because of the timing. It appeared in Boston in January 1861, too close to the outbreak of the Civil War to be given much attention. It did not help that her descriptions proved too strong for the sensitivities of her time. In other words, what "Jacobs describes would have strained the average white, Northern middle-class female reader's credulity" (Smith 2007:196, italics in 
original). The historian Robin Winks went as far as to claim that slave narratives were "the pious pornography of their day", but only for those who sought to read stories of intimate violations without losing face (Winks quoted in Ernest 2007:223). Yet even though it took a long time for Incidents in the Life of a Slave Girl to earn its place in the American literary canon, there it is now and it will most likely remain there for the foreseeable future.

\section{References:}

Bruce, Dickinson D. Jr. 2007. "Politics and Political Philosophy in the Slave Narrative" in The Cambridge Companion $28-43$.

Douglass, Frederick. 2009 (1845). Narrative of the Life of Frederick Douglass, an American Slave. New York: Oxford University Press.

Ernest, John. 2007. "Beyond Douglass and Jacobs" in The Cambridge Companion to the African-American Slave Narrative. Audrey Fisch (Ed.). New York: Cambridge University Press, pp.218-231.

Fisch, Audrey. 2007. "Introduction" in The Cambridge Companion to the African-American Slave Narrative. Audrey Fisch (Ed.). New York: Cambridge University Press, pp.1-7.

Gould, Philip. 2007. "The Rise, Development, and Circulation of the Slave Narrative" in The Cambridge Companion to the African-American Slave Narrative. Audrey Fisch (Ed.). New York: Cambridge University Press, pp. $11-27$

Grimke Weld, Angelina. 2009. "Appendix 1. The Testimony of Angelina Grimke Weld" in Narrative of the Life of Frederick Douglass, an American Slave by Frederick Douglass. New York: Oxford University Press, pp.107118.

Jacobs, Harriet. 2000 (1861). Incidents in the Life of a Slave Girl, Written by Herself. Nell Irvin Painter (Ed.). New York: Penguin Books.

Painter, Nell Irvin. 2000. "Introduction" in Harriet Jacobs. Incidents in the Life of a Slave Girl, Written by Herself. Nell Irvin Painter (Ed.). New York: Penguin Books, pp.IX-XXX.

Patterson, Orlando. 1982. Slavery and Social Death: A Comparative Study. Cambridge: Harvard University Press.

Rheid-Pharr, Robert F. 2007. "The Slave Narrative and Early Black American Literature" in The Cambridge Companion to the African-American Slave Narrative. Audrey Fisch (Ed.). New York: Cambridge University Press, pp.137-149.

Sinanan, Kerry. 2007. "The Slave Narrative and the Literature of Abolition" in The Cambridge Companion to the African-American Slave Narrative. Audrey Fisch (Ed.). New York: Cambridge University Press, pp.61-80.

Smith, Stephanie A. 2007. "Harriet Jacobs: a case history of authentication" in The Cambridge Companion to the African-American Slave Narrative. Audrey Fisch (Ed.). New York: Cambridge University Press, pp.189-200.

Stauffer, John. 2007. "Frederick Douglass' Self-Fashioning and the Making of a Representative American Man" in The Cambridge Companion to African-American Slave Narrative. Audrey Fisch (Ed.). New York: Cambridge University Press, pp.201-217. 
Weinstein, Cindy. 2007. "The Slave Narrative and Sentimental Literature" in The Cambridge Companion to the African-American Slave Narrative. Audrey Fisch (Ed.). New York: Cambridge University Press, pp.115-134.

Winter, Kari J. 1992. Subjects of Slavery, Agents of Change. Women and Power in Gothic Novels and Slave Narratives, 1790-1865. Athens: The University of Georgia Press. 